LET: Linguistics, Literature and English Teaching Journal

||Volume||11||Issue||1||Pages|||88-110||2021\|

|P-ISSN: 20869606; E-ISSN: 25492454|

Available online at: http://jurnal.uin-antasari.ac.id/index.php

\title{
FOOD, MODERNITY AND IDENTITY: ROOTED COSMOPOLITANISM IN ADICHIE'S AMERICANAH
}

\author{
Syarif Hidayat \\ kizoku9@gmail.com \\ Darma Persada University, Indonesia
}

\begin{tabular}{l} 
Article History: \\
Received: 27 February 2021 \\
Accepted: 30 June 2021 \\
\hline
\end{tabular}

\section{Keywords:}

Identity; food; Modernity of

America; Rooted

cosmopolitanism
In globalization era, there are many producers of global foods that have localized their products in order to get more costumers. Indeed, there are some people who cannot be separated with their locality, although they are part of global citizen. This paper discusses the tug-of-war between cosmopolitanism and localism within the persona of Ifemelu, the main character in Americanah, specifically in what food she eats and how the food is eaten and its influence on her identity. Americanah is a novel that tells the story of a Nigerian immigrant living in the United States who decided to return to Nigeria. The study focuses on the characters and characterization of the figures in the novel and it aims to show how a rooted cosmopolitan identity was formed in Ifemelu. The study is a qualitative research using the rooted cosmopolitanism theory proposed by Kwame Anthony Appiah. The research shows that Ifemelu's rooted cosmopolitan identity was seen through the negotiation between her cosmopolitan identity and her local (Nigerian) identity. The discourse on rooted cosmopolitanism built by the text reveals its partiality toward Nigerian local culture, specifically the Nigerian foods. 


\section{INTRODUCTION}

In the era of globalization, companies in the culinary field that have developed their industry globally, compete with each other to attract local consumers. They try to create "hybrid" products that are a mixture of their flavors with local flavors. One example of a company doing this is McDonald's, an American culinary company, which combines American flavors and local flavors in various countries. Panwar and Patra (2017) and Tanahashi (2008) concluded in their research that McDonald's goal of localizing its products was to achieve success in selling its products outside America such as India, Japan, Australia, Germany, and Brazil. In addition, in Indonesia, McDonald's also makes products that are a mixture of local and global flavors, not only foods such as "rendang" burgers, chicken with "kremes sambal uleg", satay burgers, "balado" burgers, but also drinks such as soda "kedondong", McFlurry "Markisa" and Mcflurry "rujak pedas" (Bunga \& Prodjo, 2018; Alfina, 2017). Indeed, there are some people or society who cannot accept outside tastes. Although there are some people who can accept the image of the outside, some of them always miss the image of the local taste, because basically many people find it difficult to break away from local culture. The tug-of-war between local and global cuisines is inevitable in the end. One of the novels entitled Americanah by Chimamanda Ngozi Adichie describes how the tug-of-war between local and global food takes place within the main character, Ifemelu.

The culinary theme in a literary work has become an interesting discussion in relation to cosmopolitan and identity issues. Hidayat (2016) discusses the memoir entitled Eat, Pray, Love by Elizabeth Gilbert and concludes that the text wants to open the reader's awareness to be open to differences through the main character who is able to adapt to foreign culinary delights, namely typical Italian food. Perry (2017) discusses a novel entitled This End of the Rainbow by Abidah Amin and a short story titled Deep Fried Devils by Shih-Li Kow using multicultural theory. He concluded that there is a close relationship between food and cultural identity, that on the one hand food can cause pride and a sense of belonging to a person or society towards their culture, but on the other hand food can also create identity conflicts in 
the context of a multicultural society. Pazo (2014) discusses culinary themes in the works of Asian-American writers such as Jhumpa Lahiri, May-Lee Chai, Shoba Naraya, Leslie Li, Bich Minh Nguye. He concluded that there is a connection between food and identity, "home", "belonging", that on the one hand the text shows that there are several characters who can adapt to American food, but on the other hand there are some characters who cannot adapt to American food. In contrast to the above works, the novel Americanah by Chimamanda Ngozi Adichie actually shows the tug of war between American and global food with local food through the main character, Ifemelu.

Not only the tug of war between local and global culture in terms of culinary, Americanah text also shows the tug of war between the main character's desire to become cosmopolitan in America by adopting American (western) modernity, such as a healthy lifestyle. However, on the other hand the text also shows Ifemelu who is reluctant to eat healthy food. Ifemelu, the main character of the novel Americanah, is a Nigerian who decides to continue her studies in America and become cosmopolitan there. However, the cultural clash between America and Nigeria made it difficult for her to become a cosmopolitan in America. The novel Americanah tells of Ifemelu's struggle to adapt to the culture in America. The Americanah text shows Ifemelu's ambivalence in adapting to differences in America. On the one hand, the text shows that she is able to adapt and adopt cultures in America, such as American food and modernity, but on the other hand, she is also seen as reluctant to adapt to some foods in America. In the end the text shows the tug-of-war between Ifemelu's local and national identity and her cosmopolitan identity in terms of food and American modernity

To explain this problem, this paper will use the theory of "rooted cosmopolitanism" from Kwame Antony Appiah which is somewhat different from the idea of cosmopolitanism which emphasizes the concept of universalism to unite all people in the world (Fine, 2007). Kendall, Woodward and Skrbis (2009) state that cosmopolitanism is an idea that emphasizes an attitude of being able to appreciate the differences and diversity of cultures that exist in the world. Saito 
(2011) called this cosmopolitan concept as elite cosmopolitan. A person with an elite cosmopolitan identity has more strong ties to people outside his/her country than people in his/her home country.

Appiah introduces a different viewpoint because he values more "not just of human life but of particular human lives" (Appiah, 2006, p. Xv). In his view, to be a cosmopolitan does not mean that person has to lose the cultural roots that become his/her uniqueness and identity. A cosmopolitan person can remain rooted in his/her cultural identity and have strong ties with people from his/her own country (Appiah, 2005). Appiah's opinion on partial values, such as local culture and national identity, is similar to the opinion of Beck (2006) who believes that having a cosmopolitan identity does not mean giving up one's national identity because the two will always be related. This rooted cosmopolitan theoretical framework will be used to explain the ambivalence of Ifemelu in adapting to American and global food when she enters the American cosmopolitan environment, as well as the ambivalent attitude of Ifemelu who on the one hand has a strong attachment to Nigeria, on the other hand she also adopts a modern American lifestyle.

Food is closely related to one's identity because a person's identity can be seen through the choices of food they eat (Fischler, 1988). Welsh (2018) adds that a person's identity is not only seen from what they eat but also how they eat the food, as well as how they write and talk about food. Brown (2010) explains that social conditions affect a person's food choices, that community members tend to eat food approved by community groups, and vice versa. Lien (2004) states that food is no longer just a commodity for consumption, but can also become a political discourse, which develops not only within the scope of the nation state but also in the global sphere. This food issue and its relation to self-identity are seen very strongly in the main character of the novel Americanah, so this research will focus on Ifemelu's ambivalent attitude in adopting food in relation to her choice of identity. Not only that, this research will add to how Ifemelu's identity is also seen from the way she adopted the modern American lifestyle.

Syarif Hidayat 
This research is a continuation of previous research that has discussed the novel Americanah. The novel Americanah has many interesting issues to discuss, such as race, romance, and identity. This makes many researchers interested in discussing this novel such as, Leetsch (2017) which discusses the romance issue of the novel Americanah and Guarracino (2014) which discusses the structure of the novel that combines the writing style of the Blog in Americanah. P. (2014b), Arabian and Rahiminezhad (2015), and Arafath (2017) discuss issues of racial discrimination or racism in the novel Americanah. P. (2014b) found that the return of Ifemelu, the main character of Americanah, symbolized a fight against racial discrimination that occurred in America. Arabian and Rahiminezhad (2015) concluded that Ifemelu's return was due to being alienated due to racial discrimination. Arafath (2017) concluded that Ifemelu received double oppression as a black woman. P. (2014a) and Orie (2015) discuss the issue of identity in Americanah. P. (2014a) concluded that there was a change in the identity of the two Americanah characters, Ifemelu and Obinze, who were influenced by the problems of race, poverty, and xenophobia, which both of them faced as immigrants. Orie (2015) concluded that the Ifemelu identity crisis was caused by the social conditions of American society which showed more of a dystopia, not a utopia, for an immigrant. Different from these previous studies, this study will explain how Ifemelu's ambivalence and preferences are a reflection of the tug of war between cosmopolitan identity and local identity. The tug of war between these two kinds of identities indicates a rooted cosmopolitanims discourse in the Americanah text.

\section{METHOD}

This study approaches the text using qualitative research methods and Kwame Anthony Appiah's theory of rooted cosmopolitanism. This study will describe a rooted cosmopolitanism discourse in the Americanah text. The research questions to be answered is how the tug-of-war between local and cosmopolitan is seen in Ifemelu's food choices and her adoption of the American lifestyle.

Syarif Hidayat 


\section{FINDINGS AND DISCUSSIONS}

Ifemalu's Ambivalence toward Culinary Diversity

Jonas (2013) introduces the term he calls culinary cosmopolitanism, which is a way to identify cosmopolitan identity through culinary practice through attachment to food diversity, both in the way of making and presentation. Jonas (2013) adds that someone (especially immigrants) can learn about differences in the culinary field by cooking together and sharing meals together. In the Americanah, there is a tug of war between Ifemelu's local (Nigerian) identity and her desire to be cosmopolitan in America. This can be seen from her ambivalent attitude towards differences in types of food, tastes of food, the culture of serving food and the concept of food that she encountered in America.

Americanah shows a tug of war between local and cosmopolitan in Ifemelu in addressing the differences culinary culture.

You don't need oil," Dike said. "You just cook the hot dog in water."

"Water? How can a sausage be cooked in water?"

"It's a hot dog, not a sausage."

Of course it was a sausage, whether or not they called it the ludicrous name of "hot dog," and so she fried two in a little oil as she was used to doing with Satis sausages. Dike looked on in horror. She turned the stove off. He backed away and said "Ugh." They stood looking at each other, between them a plate with a bun and two shriveled hot dogs. She knew then that she should have listened to him. (132)

In the above quotation, there is a clash of culinary cultures, which is shown through the interaction of Ifemelu and her cousin, Dike. This clash of culinary cultures involves a uniquely American food, namely hot dogs. In the above quotation, it can be seen that there are differences in perceptions about hot dogs and sausages between Ifemelu and Dike. Ifemelu represents a Nigerian immigrant who can not tell the difference between hot dogs and sausages. For Ifemelu, hot dogs are

Syarif Hidayat 
much the same with sausage, to be precise sausage "Satis", so she cooks hot dogs like cooking sausage "Satis", a famous sausage brand in Nigeria. By mentioning this trademark, it seems that the text wants to emphasize the Nigerian culinary identity which is still attached to Ifemelu as an immigrant. Thus, it can be seen that Ifemelu cultural references who recently moved to America are references to Nigerian culture that does not know hot dogs.

Whereas in the above quotation, it can be seen that Dike has no reference to satis. Also, in America, hot dogs and sausages are separate foods. Hot dog is one of the names of various types of sausage. Hot dogs were adopted by the Americans from sausages brought by the Germans. Hot dogs and sausages have the same shape, but they have some differences; First, in terms of texture, hot dogs are different from sausages. Hot dogs have a soft and chewy texture, while sausages have a denser texture. Second, hot dogs are a snack food, while sausages are usually eaten as the main food (Celine, 2011).

In Americanah, Ifemelu shows her alienation from sausages.

When, that evening, Ifemelu told Aunty Uju about the hot dog incident, Aunty Uju said with none of the amusement Ifemelu had expected, "They are not sausages, they are hot dogs."

"It's like saying that a bikini is not the same thing as underwear. Would a visitor from space know the difference?"

Aunty Uju shrugged; she was sitting at the dining table, a medical textbook open in front of her, eating a hamburger from a rumpled paper bag. (132)

The above quotation shows a comparison between immigrants who can accept differences and those who cannot. For Aunty Uju, the differences do not need to be questioned, while for Ifemelu differences are interesting things. She had just realized cultural differences in a very simple way. The text shows Aunty Uju as cosmopolitan because she can accept the difference between sausages and hot dogs. 
In addition, Aunty Uju's cosmopolitan identity can be seen when she enjoys a hamburger which is a food that is synonymous with western food, without questioning the taste. Meanwhile Ifemelu looks annoyed and cannot accept the difference between a sausage and a hot dog. This indicates that Ifemelu is reluctant to accept differences. The text also positions Ifemelu as an outsider who is alienated by these differences.

The difference between Aunty Uju who has adapted to culinary tastes in America and Ifemelu who has not been able to adapt to the taste of food in America is also seen in the following quote.

It was, also, her summer of eating. She enjoyed the unfamiliar-the McDonald's's hamburgers with the brief tart crunch of pickles, a new taste that she liked on one day and disliked on the next, the wraps Aunty Uju brought home, wet with piquant dressing, and the bologna and pepperoni that left a film of salt in her mouth. (139)

In the above quotation, there is a mention of the name of the food accompanied by the name of a fast food company, namely McDonald's hamburgers. This indicates an emphasis on food that characterizes America by the text. The Americanah text shows the different flavor variations of McDonald's hamburger in America. By presenting the typical Italian flavors "bologna" and "pepperoni" the text seems to want to carry a cosmopolitan idea in the culinary world.

In addition, in the above quotation, it is seen that Ifemelu was very aware of the taste of the new food she discovered in America. This is different from Aunty Uju who is accustomed to the taste of food in America. The quotation above shows that there is a negotiation on "unfamiliar" food. Ifemelu seems to adapt to the taste of this food and even enjoy it. However, the above quotation also shows Ifemelu's reluctance to food she does not like. Everyone seems to have a different taste sensitivity to the tongue. Someone who comes from a certain place that has food with a certain taste, sometimes cannot adapt or "survive" with food with other tastes that are owned by people from other places. Ifemelu as a Nigerian immigrant seems unable to fully adapt to the taste of food in America. Ifemelu in this case seems to 
represent a handful of people who are unable to adapt to unfamiliar food tastes that have never been encountered.

Ifemelu's reluctance to the taste of food is also seen in the following quote she would meet him at the library after his class, where they sat in the café, drinking chocolate that was too rich, eating croissants that were too grainily whole wheat, his clutch of books on the table. (383)

In the above quotation, it can be seen the names of foods and drinks that are not typical of America, namely croissants and chocolate. Croissants are food originating from Austria which is famous and is a characteristic of France. Meanwhile, the culture of drinking chocolate is a culture of Latin American society which was adopted by Europeans. Chocolate and croissants seem to be symbols of globalized food and drink because almost all countries are familiar with these foods and drinks. In the above quotation, it can be seen how Ifemelu does not like the taste of chocolate and the taste of croissants made from "whole wheat" in America. From the tone of the text, it can be seen that the taste of croissants and chocolate in America is very strange to her. The text shows chocolate and croissants as universal foods that have a different taste when adopted by other countries. The text shows how Ifemelu commented that this food is "too rich", namely food or drinks that contain a lot of fat, are too tasty and sweet. In addition, she also seems to dislike the texture of the croissants she eats, which according to her is "too grainily whole wheat", which is by using flour that is still coarse but healthier. This may be due to the taste of croissants and chocolate that is different from what she had previously eaten. The narrative above shows the difference between Blaine and Ifemelu. Ifemelu is still influenced by her "local tongue" so that she cannot accept the taste of food that is different from the one in Nigeria, which is found in America. In this case, Blaine as a cosmopolitan who is able to adapt to the varied taste of food in a global scope tends to intimidate Ifemelu. 
Furthermore, Americanah also shows Ifemelu's reluctance to fruit flavours in America

She was disoriented by the blandness of fruits, as though Nature had forgotten to sprinkle some seasoning on the oranges and the bananas, but she liked to look at them, and to touch them; because bananas were so big, so evenly yellow, she forgave them their tastelessness. Once, Dike said, "Why are you doing that? Eating a banana with peanuts?"

"That's what we do in Nigeria. Do you want to try?"

"No," he said firmly. "I don't think I like Nigeria, Coz." (139)

Oranges and bananas are fruits that can be found in almost all countries in the world. It's just that each country seems to have different types of citrus fruits and bananas, or even have different ways of eating fruit. The above quotation shows the differences between oranges and bananas in Nigeria and America. This can be seen from how the text seems to make these two fruits seem foreign to Ifemelu as an immigrant in America. In the quotation above, it can be seen that Ifemelu's ambivalence towards these two fruits is seen from the use of the words disoriented and forgave. On the one hand she does not like the taste of this fruit but on the other hand she likes the shape and color. The interesting thing is how she is depicted eating a banana with nuts, which seems to have the aim of producing a taste that matches her tongue. The text seems to want to indicate that Ifemelu has an "African or Nigerian tongue", this can be proven by the statement that "Africans often eat nuts with various other foods such as bananas". Thus, her difficulty in adapting to the taste of certain foods in America is a result of Nigerian culinary roots, especially regarding taste, which is still strong in her. In addition, the way Ifemelu eats bananas with peanuts can also indicate her negotiations on the taste of fruit in America.

Meanwhile, in the above quotation, it can be argued that Dike also has an attachment to American locality which makes it difficult for him to accept a different taste. American locality was even attached to Dike when he was in Nigeria. They stopped at a fast-food place, where he ordered a hamburger. "Is this horse meat? 
Because it isn't a hamburger. " Afterwards, he would eat only jollof rice and fried plantain. (518). The text shows that Dike is tied to American locality. The hamburger that he likes the taste and texture is the American hamburger. Interestingly, the text shows how Dike prefers to eat foreign foods at the same time, namely "jollof rice" and "fried plantain".

In addition to the depiction of food that has a taste that is foreign to Ifemelu in America, the text also describes a food that tastes no different. This can be seen from the following quotation; "Ice cream was, fortunately, a taste unchanged. She scooped straight from the buy one-get one free giant tubs in the freezer, globs of vanilla and chocolate". Ice cream is used as a symbol of universalism in this text because it is described as having an unchanging taste, in the sense that both in Nigeria and in America the taste of ice cream remains the same. However, this narrative actually seems to indicate that Ifemelu herself is actually a "reluctant" figure to accept differences, especially in culinary matters. She is more grateful for the taste of food or drink that is not different, this can be seen from the text narrative that uses the word "Fortunately".

Apart from showing a sense of reluctance towards food in America, Ifemelu also shows her ability to adapt to food differences. This can be seen when she interacts with Dike and can learn from her mistakes.

"Can I have a peanut butter and jelly sandwich instead?" Dike asked. She followed his instructions for the sandwich, cutting off the bread crusts, layering on the peanut butter first, stifling her laughter at how closely he watched her, as though she just might decide to fry the sandwich. (132)

Through interactions between people of different cultures one seems to be able to learn to be open about the differences themselves. This is shown in the above quotation. Ifemelu finally followed Dike's way of making sandwiches, a popular American food originating from Europe. In addition, Ifemelu's ability to adapt to typical American food is also seen when she "orders a" muffin "without thinking that it really was a cake" (166). Ifemelu is able to eat a typical American muffin that is different from the muffins she knows without comment in her mind, which is an 
American muffin that looks like a "cupcake", while the muffin that Ifemelu is known for, as an immigrant who comes from Nigeria, which belongs to the British Commonwealth, is "English muffins" which are round like bread, which are famous in the British Commonwealth. By showing Ifemelu's ability to adapt and be open to culinary differences, especially how to treat food, the text shows that Ifemelu has the potential to become a cosmopolitan.

Ifemelu get the cosmopolitan identity in America, she brought this identity to Nigeria. However, it must clash again with her Nigerian identity.

"Oh, there's this new place that opened on Akin Adesola," Bisola said. "The brunch is really good. They have the kinds of things we can eat. We should go next Sunday."

They have the kinds of things we can eat. An unease crept up on Ifemelu. She was comfortable here, and she wished she were not. She wished, too, that she was not so interested in this new restaurant, did not perk up, imagining fresh green salads and steamed still-firm vegetables. She loved eating all the things she had missed while away, jollof rice cooked with a lot of oil, fried plantains, boiled yams, but she longed, also, for the other things she had become used to in America, even quinoa, Blaine's specialty, made with feta and tomatoes. This was what she hoped she had not become but feared that she had: a "they have the kinds of things we can eat" kind of person. (502-03)

The above quotation shows a culinary culture related to meal times, namely brunch, which is a culinary culture that is often identified with urban culture and also the upper-middle class. Brunch can be said to be a global culture, which originally comes from England and the United States, but was later adopted by other countries, especially in urban areas. In the quotation above, it can be seen that Ifemelu has ambivalence to accept urban culture that is identical to the western culture. On the one hand, Ifemelu can accept the culture of "brunch", on the other hand there is a reluctant attitude of Ifemelu to the culture of "brunch". The text shows Ifemelu's reluctant attitude because she wants to be a Nigerian who likes Nigerian 
food, but on the other hand she realizes that she has become, "Americanah", an American who likes American food.

Also, In the above quotation the text divides culinary culture into three. First, Nigeria's local culture is represented by jollof rice, fried plantains, and boiled yams, all of which are unhealthy foods from the perspective of the Nigerian community who returned from America. Second, global culture which is represented by "brunch" through its healthy foods, namely fresh green salads and steamed still-firm vegetables. The third is local American food, namely quinoa made with feta (white cheese) and tomatoes. From this, it can be seen that there is a clash between the three cultures. Ifemelu's attitude in accepting global culture and also her nostalgia for American local culture, shows that she has a cosmopolitan identity. However, Ifemelu's reluctant attitude towards brunch culture, as well as her nostalgic attitude towards (local) Nigerian culinary culture, indicates her strong local identity.

Ultimately it appears that Ifemelu has hybrid tastes because she likes local Nigerian tastes and the universal "healthy" taste from America. Although it can be seen in the above quotation that Ifemelu only wants to have one identity. However, this is not possible, because both of them have become part of Ifemelu.

\section{Ifemelu's Ambivalence toward American Modernity}

Western modernity produced by the industrial revolution is increasingly widespread throughout the world in the era of globalization. Appiah (2005) states that western modernity can influence a person's identity. In the era of globalization, western modernity can mix with one's racial identities which eventually form a new identity. Americanah shows how western modernity, such as a healthy lifestyle with healthy food, and modern journalistic writing styles, influence the identity of its main character, Ifemelu.

Americanah shows Ifemelu process of adopting a healthy American lifestyle through healthy food. A healthy lifestyle or diet shows a person's identity. Ifemelu, who wants to be cosmopolitan in America, tries to adopt a healthy American lifestyle, by adapting it to healthy foods. Several factors seem to motivate her to eat 
healthy foods and follow the healthy lifestyle of Blaine, Ifemelu's boyfriend, one of which is that a healthy lifestyle can improve her quality of life. In addition, Ifemelu seems to really admire Blaine, who has a broader insight than herself, for that she is willing to adopt Blaine's healthy habits.

He cooked organic vegetables and grains whose names she could not pronounce-bulgur, quinoa-and he swiftly cleaned up as he cooked, a splatter of tomato sauce wiped up as soon as it appeared, a spill of water immediately dabbed at. He frightened her, telling her about the chemicals that were sprayed on crops, the chemicals fed to chickens to make them grow quickly, and the chemicals used to give fruits perfect skin. Why did she think people were dying of cancer? And so before she ate an apple, she scrubbed it at the sink, even though Blaine only bought organic fruit. He told her which grains had protein, which vegetables had carotene, which fruits were too sugary. He knew about everything; she was intimidated by this and proud of this and slightly repelled by this. (383)

In the above quotation, it can be argued that Blaine is positioned as "the other" in the text, because he has a different culture from Ifemelu, namely the culinary culture of healthy food. The concept of healthy food at Blaine can be seen from the organic food he uses. By eating organic food, which tends to be more expensive, Blaine also represents classy African-American. Organic food is a food whose cultivation process is completely natural, without chemicals, pesticides, and other artificial processes. The concept of organic food seems unknown to Ifemelu. The above quotation shows an introduction to organic food culture from Blaine to Ifemelu. In addition, the above quotation also shows the foods that are not typical American food, namely Bulgur and quinoa. Bulgur, a popular grain type in Europe, India, and the Middle East. While quinoa is a type of grain that is popular in South America, it is starting to spread and is also becoming popular in countries such as the United States, Canada, European countries, China and Japan. The text seems to represent a global, healthy diet through bulgur and quinoa. However, in this case the text illustrates that Ifemelu as a Nigerian immigrant is unlikely to be familiar with 
this type of grain food. The interaction between Blaine and Ifemelu shows an interaction between two people of different cultures. One person introduces a culture to another. Ifemelu tries to be cosmopolitan in America by adapting and accepting the culinary culture that Blaine introduced. This is shown in the above quotation when Ifemelu washes her apples. Although there is an irony in the text that Ifemelu itself does not have a complete concept of what is called organic food or healthy food. Blaine himself is shown to have the potential to be cosmopolitan because he can accept non-American culinary cultures such as bulgur and quinoa. This is because the awareness of the concept of healthy living by eating healthy foods is stronger than a preference for certain foods.

Thus, the text shows the contradiction of Ifemelu's identity. Ifemelu's desire to become a cosmopolitan in America collides with Ifemelu's character who is humble but does not like to be overthrown or dominated. Ifemelu feels Blaine's knowledge intimidates him. But on the other hand she was also amazed by Blaine's knowledge.

she imagined a crib in the bedroom, a baby inside it, and Blaine carefully blending organic fruits for the baby. He would be a perfect father, this man of careful disciplines.

“I can't eat tempeh, I don't understand how you like it," she told him.

"I don't like it."

"Then why eat it?"

“It's good for me."(384)

In the above quotation, it can be seen that tempeh is a healthy food. Tempeh is known as a protein rich food. Tempeh itself is a typical Indonesian food, which spreads to all countries in the world such as European countries, Australia, Canada, the United States, Japan and others. Tempeh has become popular in America as a daily diet menu since 1980. From the above quotation, it can be seen that there are differences in food concepts between Ifemelu and Blaine. Ifemelu tends to choose foods that have a taste while Blaine tends to choose healthy foods even though he 
doesn't really like the taste, like tempeh. Unlike Ifemelu, Blaine can actually accept tempeh as a healthy food, even though he doesn't like the taste itself. This shows that the awareness of healthy living goes beyond liking and disliking food, and beyond one's cultural identity and locality.

What's interesting is that when Ifemelu quarreled with Blaine she actually ate food that Blaine didn't like.

It had given her pleasure, buying chocolate bars from the newsstand, cheap bars filled with sugar and chemicals and other genetically modified ghastly things.

"Oh, so because you are quarreling with Blaine, you are now eating the chocolate he doesn't like?" Aunty Uju laughed. (432)

Ifemelu initially did not have a concept of healthy food. Her desire to be cosmopolitan in America made her adapt to Blaine's healthy lifestyle. But when she quarreled with Blaine, he finally returned to his usual lifestyle, which is eating unhealthy foods. In other words, Ifemelu returns to her cultural roots.

Furthermore, based on the interaction between Ifemelu and Blaine, the text seems to show the relationship between repressive cultures.

"They did not fight again until the relationship ended, but in the time of Blaine's stoniness, when Ifemelu burrowed into herself and ate whole chocolate bars, her feelings for him changed She still admired him, his moral fiber, his life of clean lines, but now it was admiration for a person separate from her, a person far away. (437)"

Blaine wanted Ifemelu to follow his lifestyle. This made Ifemelu feel intimidated. Blaine, who already has an American identity and no longer has an African identity, feels that the American healthy lifestyle is the best lifestyle to follow. He feels the other lifestyle is unhealthy and unkind. This has indirectly repressed Ifemelu. The problem of differences in culinary culture, the lifestyle of eating healthy foods, can even be a big problem. In this quotation, it can be seen that 
Ifemelu is a person who wants individual freedom to be respected. In the end, through Ifemelu and Blaine's relationship, a repressive kind of relationship is seen.

Although, Ifemelu in the end prefers to eat the food she likes, but the healthy lifestyle she has learned from Blaine still seems to be attached to her. This can be seen from the below quotation which shows that she still brings healthy food after she broke up with Blaine. This shows the ambivalence in Ifemelu.

"Your hair take long. You need food," Aisha said.

"I'm fine. I have a granola bar," Ifemelu said. She had some baby carrots in a Ziploc, too, although all she had snacked on so far was her melted chocolate.

"What bar?” Aisha asked.

Ifemelu showed her the bar, organic, one hundred percent whole grain with real fruit.

“That not food!" Halima scoffed, looking away from the television.

"She here fifteen years, Halima," Aisha said, as if the length of years in America explained Ifemelu's eating of a granola bar.

“Fifteen? Long time,” Halima said. (47)

In the above quotation, healthy foods such as "granola bars" and "baby carrots" are still an alternative choice for Ifemelu, however she prefers chocolate. This shows that Ifemelu has ambivalence, on the one hand she prefers food that tastes she likes, but on the other hand she still brings and makes healthy food as an alternative to her other choices. Apart from that, from Halima and Aisha's point of view, Ifemelu has also become an American because she has adapted to American habits, by making "granola bars" as an alternative food. Thus the text shows a tug of war between Ifemelu's cosmopolitan identity, which can adapt to a healthy American lifestyle, and her identity that tends to choose the food she likes the taste of.

Syarif Hidayat 
Apart from going through the healthy American diet, Ifemelu also adopts another healthy lifestyle through Blaine.

He ran every morning and flossed every night. It seemed so American to her, flossing, that mechanical sliding of a string between teeth, inelegant and functional. "You should floss every day," Blaine told her. And she began to floss, as she began to do other things that he did-going to the gym, eating more protein than carbohydrates — and she did them with a kind of grateful contentment, because they improved her. He was like a salutary tonic; with him, she could only inhabit a higher level of goodness. (384)

The above quotation shows that Blaine is an African-American who has followed the American lifestyle. Blaine's lifestyle no longer reflects the stereotype of African-American who do not care about health. Blaine's identity is an American identity. Through Blaine's awareness of healthy living, this can also prove that Blaine represents a classy African-American. Meanwhile, Ifemelu, who wants to be a cosmopolitan in America, finally adapts and follows Blaine's healthy American lifestyle.

Apart from going through a healthy lifestyle with healthy food, the text also shows how Ifemelu applied American modernity in her journalistic field. Ifemelu who studied in America adopted modern liberal American thought, which is a thought that prioritizes pluralism and freedom of opinion and expression with different beliefs, moral values, and philosophies (Adams and Dyson, 2007).

"The idea of interviewing someone and writing a profile is judgmental," Ifemelu said. "It's not about the subject. It's about what the interviewer makes of the subject."

Aunty Onenu shook her head. Doris shook her head.

"Why do we have to play it so safe?" Ifemelu asked.

Doris said, with false humor, "This isn't your American race blog where you provoked

Syarif Hidayat 
everybody, Ifemelu. This is like a wholesome women's magazine?"

The above quotation debates the problem of Ifemelu's writing, which is honest and straightforward, regarding Mrs. Funmi King who never saw his servant when talking. In making her writing, Ifemelu uses a provocative writing style that her superiors disapprove of. Ifemelu started writing and studying communication science in America, which is known for being liberal and everyone is free to argue. In addition, she also wrote for the first time on her blog that talked about racism, which is an insult to human values. This is what makes Ifemelu want to write with fairness values. This way of writing is deprived of a modern and liberal writing style that she adopted from America. Ifemelu's article which was disapproved of finally made Ifemelu decide to leave and write her own blog about justice in Nigeria. Based on this, Ifemelu's ambivalence is seen, on the one hand she writes to advance Nigeria but on the other hand she writes based on her experiences in America.

Based on the above analysis, it can be seen that Ifemelu's ambivalence towards American modernity. On the one hand, Ifemelu is able to adapt to American modernity such as a healthy lifestyle, but on the other hand, she also shows his reluctance to eat healthy foods. This is because Ifemelu prefers food she likes rather than healthy food that she doesn't like. The text also shows a paradox within Ifemelu, namely that she uses the modern liberal American thinking style in her writings fighting for her country, Nigeria. Finally, it shows once more that both, American (cosmopolitan) and Nigerian (local or national) identity, has become part of Ifemelu.

\section{CONCLUSIONS AND SUGGESTIONS}

Ifemelu's identity does not fully meet "Americanah" (Nigerian who come home from United States of America and follow the whole American lifestyle) criteria suggest that this text offers a deeply rooted cosmopolitan identity. Ifemelu's rooted cosmopolitan identity is seen through the paradox of her attitude towards American culinary and American modernity. The paradox of Ifemelu's attitude towards American culinary is seen through how on the one hand Ifemelu is able to 
adapt to American and global food, but on the other hand, she cannot leave Nigerian food. Furthermore, the paradox of Ifemelu's attitude towards American modernity can be seen from how on the one hand Ifemelu is able to adapt to American modernity such as a healthy lifestyle with healthy food, but on the other hand she shows a reluctance to eat healthy food and make it a second alternative.

The text also shows its ideology by constructing a rooted cosmopolitanism discourse. The tug of war between Ifemelu's comopolitan identity and its Nigerian identity shows that Ifemelu has a deeply rooted cosmopolitan identity. Appiah (1997) gave an example by quoting Getrude Stein who stated that "America is my country, and Paris is my hometown (p. 618)." This also happened in Ifemelu. Although she feels comfortable living in America and feels that America is her second place, she feels Nigeria is her home and she must maintain her culture and be selective about American culture. This proves that cosmopolitan identity and local or national identity cannot be separated. Appiah (2005) states that "If cosmopolitans are never fully cosmopolitan, the locals are never fully local" (p. 239). The tug-of-war between local identity and Ifemelu's cosmopolitan identity indicates that she does not fully have a local identity or a cosmopolitan identity, but rather that these two identities merge into Ifemelu who form her rooted cosmopolitan identity.

The text shows that there is a demand from the dominant culture that in order to have a cosmopolitan identity, a person, especially immigrant, must adapt to dominant cultures such as western culinary, American healthy lifestyle and healthy food, and modern American mindset. However, the text also displays resistance to this pressure by presenting a character who refuses to fully submit to this dominant culture even though she has the ability to meet the criteria set by the dominant culture. This shows that the Americanah text views the importance of local identity in the formation of one's cosmopolitan identity. In this way the text builds a deeply rooted cosmopolitanism discourse to show its readers that maintaining a local or national culture, in this case local cuisine and nationalism towards the state, is important. The rooted cosmopolitan identity shown in the text is basically a dialogue 
or negotiation to be able to maintain local culture while still being able to become citizens of the world. Indirectly, by raising the notion of a rooted cosmopolitan identity, the text shows that the strength of local and national identity can avoid the influence of cultural imperialism and western hegemony which continues to strive to maintain western culture as a dominant culture that is universal.

\section{REFERENCES}

Adams, I dan Dyson, R.W. (2007). Fifty Major Political Thinkers. London dan New York: Routledge.

Adichie, C. N. (2014). Americanah. New York: Anchor Books.

Appiah, K. A. (1997). Cosmopolitan Patriots. Critical Inquiry, 23(2), 617-639. http://www.jstor.org/stable/1344038

Appiah, K. A. (2005). The Ethics of Identity. New Jersey: Princeton University Press.

Appiah, K. A. (2006). Cosmopolitanism: Ethics in a World of Strangers. New York: W. W. Norton

Arabian, S. \& Rahiminezhad, V. (2015). Journey and Return: Visiting Unbelonging and Otherness in Adichie's Americanah. Journal UMP Social Sciences and Technology Management, 3(3), 536-541. https://www.researchgate.net/publication/328957051_Journey_and_Retur n_Visiting_Unbelonging_and_Otherness_In_Adichie\%27s_Americanah

Arafath, M. Y. (2017). Race and Gender Discrimination. Pune Research: An International Journal in English, 3(2), 1-8. http://puneresearch.com/media/data/issues/58b9c43a1ec60.pdf

Beck, U. (2006). The Cosmopolitan Vision. (terj. Ciaran Cronin). Cambridge \& Malden: Polity Press.

Brown, A. (2011). Understanding food: Principles and preparation (4th ed.). Belmont, CA: Wadsworth.

Fine, R (2007). Cosmopolitanism. London and New York: Routledge.

Fischler, C. (1988). "Food, Self and Identity". Social Science Information, 27(2): 275-292.

https://www.researchgate.net/profile/Claude_Fischler/publication/232475

763_Food_Self_and_Identity/links/0deec51a472598c937000000/Food-

Self-and-Identity.pdf

Guarracino, S. (2014). Writing «so raw and true» : Blogging in Chimamanda Ngozi

Adichie's Americanah. Between, IV (8), 1-27.

http://ojs.unica.it/index.php/between/article/download/1320/1173

Syarif Hidayat

LET: Linguistics, Literature and Language Teaching Journal Vol. 11 No. 12021 
Hidayat, S. (2016). Kosmopolitanisme dalam Memoar Eat, Pray, Love Karya Elizabeth Gilbert. In D. Ekawati, I.N. Azhar \& E.C. Sari (Eds). Seminar Nasional Bahasa dan Sastra: SENABASTRA (pp. 317-322). Bangkalan: Universitas Trunojoyo Madura.

Jonas, T. (2013). Eating the Vernacular, Being Cosmopolitan. http://epress.lib.uts.edu.au/journals/index.php/csrj/article/viewFile/3076/34 $\underline{28}$

Kendall, G. et al. (2009). The Sociology of Cosmopolitanism: Globalization, Identity, Culture and Government. New York: Palgrave Mcmillan.

Kurniasari, A. (2017). 5 Menu McDonald's's dengan Rasa Khas Indonesia yang Pernah Ada. https://www.idntimes.com/food/dining-guide/afinakurniasari/5-menu-mcdonalds-dengan-rasa-indonesia-banget-c1c2/3

Leetsch, J. (2017). Love, Limb-Loosener: Encounters in Chimamanda Adichie's Americanah. Journal of Popular Romance Studies, 6, 1-16. http://jprstudies.org/wp-content/uploads/2017/04/LLL.4.2017.pdf

Lien, M. E. and Nerlich, B. (Eds). 2004. The Politics of Food. Oxford: Berg.

Orie, C. P. (2015). Women Meet Dystopia in Their America: A Femalist Reading of Americanah. Okike. An African Journal of New Writing, 53, 66-75. https://oer.unn.edu.ng/read/women-meet-dystopia-in-their-america-afemalist-reading-of-americanah/file.pdf

P., S. (2014a). The lost “Africanah' in Chimamanda Ngozi Adichie's Americanah. GJRA-global Journal for Research Analysis, 3(11), 42-43. https://www.worldwidejournals.com/global-journal-for-research-analysisGJRA/fileview/November_2014_1564832279_15.pdf

P., S. (2014b). Unmasking Racism in Chimamanda Ngozi Adichie's Americanah. GJRA-global Journal for Research Analysis, 3(11), 42-43. https://www.worldwidejournals.com/indian-journal-of-applied-research(IJAR)/file.php?val=November_2014_14927743323_79.pdf

Panwar, D., and Patra, S. (2017). Localization in Fast Food Industry: A Case Study on McDonald's's Strategy in India. Journal of Arts, Scinece \& Commerce, VIII, $3(1)$. https://www.researchgate.net/publication/318470523 LOCALIZATION IN_FAST_FOOD_INDUSTRY_A_CASE_STUDY_ON_MCDONALD' S'S_STRATEGY IN_INDIA/link/5983402d45851531048f8ab0/downloa $\underline{\mathrm{d}}$

Pazo, P. T. (2014). Diasporic Tastescapes: Intersections of food and Identiy in Asian American Literature. A Doctoral Thesis. Universidade Da Coruna. https://core.ac.uk/download/pdf/61910855.pdf

Perry, M. S. (2017). Feasting on Culture and Identity: Food Functions in a Multicultural and Transcultural Malaysia. The Southeast Asian Journal of English Language Studies, 23(4), 184-199. 
https://www.researchgate.net/publication/322102513_Feasting_on_Cultur e and_Identity_Food_Functions_in_a_Multicultural_and_Transcultural Malaysia/link/5caeb27b4585156cd78f668d/download

Rombauer, I. S., Becker, M. R., Becker, E. (2001). Joy of Cooking: All About Breakfast and Brunch. New York: Scribner.

Saito, H. (2011). An Actor-Network Theory of Cosmopolitanism. American Sociological Association. Sociological Theory, 29, 2, 124-149. http://www.jstor.org/stable/23076374

Saputra, G. B. and Wahyu A. P. (2018). Di McDonald'ss Ada Burger Rendang hingga Soda Kedondong. https://travel.kompas.com/read/2018/08/11/131000327/di-McDonald'ssada-burger-rendang-hingga-soda-kedondong

Tanahashi, S. (2008). Succeeding Globally Depends on Localization: A Case Study on McDonald's's Corporation. https://www.ubunkyo.ac.jp/center/library/image/fsell2008_057-073.pdf

Welsh, S. L. (2018). Culinary Cultures: Food and the Postcolonial. Journal of Postcolonial Writing, 54 (4), 439-441. https://www.tandfonline.com/doi/full/10.1080/17449855.2018.1497763 